\title{
Mergers, Acquisitions and Corporate Performance: The Balanced Scorecard Approach
}

\author{
Oghuvwu, M. E ${ }^{1}$ (M.Sc) \& Omoye, A.S ${ }^{1}$ (Ph.D, ACA) \\ ${ }^{1}$ Department of Accounting, Faculty of Management Sciences, University of Benin, Benin City, Nigeria \\ Correspondence: Omoye, A. S. (PhD, ACA), Department of Accounting, Faculty of management Sciences, \\ University of Benin, Benin City, Nigeria. \\ Received: August 24, 2016 \\ Accepted: September 18, 2016 \\ Online Published: September 20, 2016 \\ doi:10.5430/afr.v5n4p63 \\ URL: http://dx.doi.org/10.5430/afr.v5n4p63
}

\begin{abstract}
The broad objective of this paper is to evaluate the impact of mergers and acquisitions on corporate performance, using the five dimensions of financial performance, learning and growth, customer satisfaction, internal business process and environment. An ex-post study approach was used to extract pre- and post- merger information of selected banks in Nigeria, however, five banks formed the sample for the study. The data set consists of 11 years from (2000 - 2010), with five years pre and five years post analysis. Consequently, data obtained was then analysed using descriptive statistics and the paired t- test of differences as the problem under examination is a pre- and posteffect. The study finds a significant impact of mergers and acquisitions on the financial performance, customer satisfaction and learning and growth. However, the observed impact was not statistically significant in the environmental and internal business process performances $(p>0.05)$. Against the backdrop of the findings, the study recommends the establishment of an environmental management and audit system, which will take cognisance of environmental management issues and also research and development initiatives should be planned, in other to achieve the best possible utilisation of organisations internal business processes.
\end{abstract}

Keywords: Mergers, Acquisitions, Balanced Scorecard, Corporate Performance

\section{Introduction}

Business combination has emerged as a vital corporate strategy designed to achieve rapid growth and value creation in organisations. The International Financial Reporting Standard (IFRS) No.3 describes a business combination as "transactions or other events in which an acquirer obtains control of one or more businesses". Among the several forms of business combinations are the Mergers and Acquisitions (M\&A). Afolabi (2011) defines a merger as the coalescing of two firms to form a new entity while an acquisition is described as a transaction which involves a "takeover" of another firm. M\&A transactions are predominantly driven by the need to achieve organisations' strategic objectives, such as increased market share, revenue, economies of scale, synergistic advantages and tax benefits (El-Zuhairy, Taher \& Shafei, 2015 and Sherman, 2011). As a key corporate strategy, M\&A plays a crucial role in the long-term sustainability of corporations. Therefore in taking such decisions, organisations have to keep in view critical strategic issues, such as financing, corporate governance and performance decisions. Ismail, Abdou and Annis (2011) further state that the concept of M\&A is a laudable strategy in theory, but challenging in actual practice. For instance, the decision to venture in M\&A may be driven by personal or selfish motives of management and the expected economies of scale may sometimes be unrealistic. Similarly, the process of merger can lead to loss of strategic focus with significantly negative impact on business performance (Ashfaq, 2014 and Omoye \& Aniefor, 2016). Consequently, the need for the acquiring company to adopt an effective system in evaluating the expected synergistic advantages causal to improving the overall corporate performance of the firm is imperative.

Improving corporate performance through M\&A is mainly considered as a management strategy. Previous studies such as Ismail, Abdou and Annis (2011); Shimizu and Hitt (2005) and Sudarsanam and Mahate (2006) document that the traditional financial measures of performance consisting mainly of accounting based measures and market-based measures were employed in measuring the post- M\&A corporate performance. Despite the preponderance of evidence in favour of the traditional measures of performance, there exist some limitations that may undermine their reliability (Wang \& Moini, 2012). For example, using the stock returns as a measure of performance may not take into cognisance the diverse motives of M\&A. Also, performance is measured from what is expected rather than the realised synergy. Conversely, the accounting measures may not be totally reliable, as it 
measures performance in short-term. In addition, the accounting policy, choice of financing and accounting methods may vary within countries.

Accordingly, there is a need for a measurement system that can give a more comprehensive and faster view of corporate performance in line with the diverse motives of mergers and acquisitions. This attribute is apparent in strategic performance measurement systems such as the Balanced Scorecard (BSC). The BSC measures organisational performance in both financial and non-financial dimensions which include internal business process, customer satisfaction and learning and growth (Kaplan \&Norton, 1992). However, the existing model is limited by the fact that it does not measure organisations' impact on host communities. Against the backdrop of this limitation, we modified the existing model by introducing an environmental dimension. This is hence a modest contribution to the growing literature of the BSC. Therefore, this study advances a modified balanced scorecard as a measure of preand post- mergers and acquisitions performance. The rest of the paper is structured as follows: Section two focuses on an empirical review of literature, section three emphasises the research methodology, presentation and discussion of results and section four concludes the study.

\section{Literature Review and Hypotheses Development}

\subsection{The Concept of Mergers and Acquisitions (M\&A)}

Mergers and acquisitions are measures firms adopt to achieve external expansion (Oh, Peter \& Johnson, 2014). According to Sheidu and Yusuf (2015) mergers is defined as the blending of two or more companies. In the broad sense, M\&A encompasses the coming together, combination, fusion and synergy of companies, in which one drop its identity, and the other retains. Anyanwu and Agwor (2015) see mergers as a form of "strategic alliance" whereby two firms work together in pursuance of similar objectives. Similarly, Ahmed and Ahmed (2014) described mergers as an amalgamation that involves the combining of two previously independent entities subsequently into a sole entity. This can be achieved through "Absorption or Consolidation". An absorption is achieved were one of the entities retains her name (Anyanwu \& Agwor, 2015).

Conversely, an acquisition which is often used interchangeably can be referred to as "take-over". Akinbuli and Kelilume (2013) defined an acquisition as a form of combination whereby one firm "takes over" the assets and liabilities of the other in return for a consideration. Similarly, Ahmed and Ahmed (2014) referred to an acquisition as a situation where one company acquires successful control of the asset and management of another. In acquisitions, the combining entities may retain their legal entities, but however, control is vested in one (Omoye \& Aniefor, 2016). According to Guaghan (2007), mergers and acquisitions fall into three categories: first, is the horizontal merger, which involves the combination of firms in the same area of business. Secondly, is the vertical merger, which involves the integration of firms in the same industry, but within varying business stages. Thirdly, is the Conglomerate merger, described as a combination of firms in dissimilar operations.

\subsection{Corporate Performance}

Corporate performance depends on various factors and can be studied from different aspects. Some believe that corporate performance should be measured by financial figures while for some companies corporate performance depends on customers' loyalty or other qualitative measures (Ansari \& Riasi, 2016). However, prior studies on mergers and acquisitions performance have viewed performance from two schools of thought; the accounting based measures and the stock market approach (Grigorieva \& Petrunina, 2015; Ismail, Abdou \& Annis, 2011 and Wang \& Mioni, 2012). The accounting based approach is founded on the assumption that the objectives of M\&A are to increase financial numbers. This school of thought believes that the synergistic effect of M\&A is reflected in profitability measures (Anderibum \& Obute, 2015; Kouser \& Saba, 2011 and Olagunju \&Obademi, 2012). The second school of thought which is the stock market approach is premised on the idea that performance is reflected in the increase in stock returns. It is based on stock price changes and returns of post-M\&A announcement (Ismail, Abdou \& Annis, 2011; Rani, Yadav \& Jain, 2015 and Wang \& Mioni, 2012). A broader approach is the balanced scorecard approach developed by Kaplan and Norton in 1992. The Balanced Scorecard (BSC) is a multi-dimensional performance measurement and management tool that translates an organisations' vision and strategy into action (Rigby \& Bilodeau, 2013). It measures performance in four perspectives: financial, customer satisfaction, internal business process and learning and growth (Kaplan \& Norton, 1996). This measurement model, however, suffers a shortcoming, such that it ignores the costs the society incurs as a result of externalities from business (Etim \& Agara, 2011). There is thus the need for a dimension such as the environment that incorporates these externalities. Based on this limitation, we review performance from the financial, customer satisfaction, learning and growth, internal business process and environment subsequently. 


\subsection{Mergers \& Acquisitions (M\&A) and Perspectives of Performance}

\subsubsection{Mergers \& Acquisitions and Financial Performance}

The financial performance assesses the profitability of the organisation actions. It examines how an organisation should appear to its shareholders to succeed financially (Kaplan \& Norton, 1992). Anderibum and Obute (2015) evaluated the outcomes of M\&A on the bank profitability in Nigeria. The study focused on the United Bank for Africa (UBA) Plc, spanning a period of 2000 - 2010. Using paired sample t-test the study found a positive and significant relationship on the performance of commercial banks in Nigeria. Similarly, Omoye and Aniefor (2016) employed a longitudinal survey covering the period of 2007 to 2012 to assess the effect of M\&A on organisations' profitability. Data for the study was analysed using "McNemar" statistics. The findings from the study revealed that M\&A has an influence on the profitability ratios. Another study of Rani, Yadav and Jain (2015) investigated the effect of M\&A on stock returns. The study adopted the event study methodology and consequently their findings suggested significant positive abnormal returns. In their conclusion, the positive returns were attributed to the motive of the combination, which was basically strategic. In the same vein, Sabri, Ezman and Zainal (2015), examined the impact of M\&A on the stock price. Their study demonstrated evidence that suggests a positive and significant impact of M\&A on stock performance. They further assert that when M\&A are announced this may spur efficiency.

However studies such as Ahmed and Ahmed (2014); Ashfaq, Usman, Hanif and Yousa (2014) argued that M\&A have no effect on corporate performance. Ashfaq et al. (2014) investigated the effects of M\&A on corporate performance, using descriptive statistics and paired sampled t-test. Their study revealed that performance declined following mergers and acquisitions. They further observed that organisations tend to loss strategic focus after business combination. The study of Ahmed and Ahmed (2014) also conforms to the previous findings. They examined the impact of mergers on financial performance. The sample was drawn from selected manufacturing industries of Pakistan covering 2000-2009. Using paired sample t- test statistics, they found a negative relationship between mergers, acquisitions and firms' performance. Against the above background, we hypothesise that H1: There is no significant difference between pre- and post-M\&A financial performance.

\subsubsection{Mergers \& Acquisitions and Customer Satisfaction}

According to Kaplan and Norton (1992), the customer dimension focuses on customer sustainability and satisfaction measures. The growth in customer satisfaction has been linked with companies increased market share, which consequently resulted in improved profits and corporate image. Oberg (2014) pointed out that a major issue in postmergers and acquisitions are the organisations' ability to establish a continued customers' relationship and service quality. Johnson, Ernest and Samuel (2015) examined the impact of M\&A on customer service quality of banks in Ghana. The study employed a descriptive and explanatory methodology, using analysis of variance and paired t- test for data analysis. The findings from their study revealed a positive impact of M\&A on customer satisfaction through an improvement in organisations' service quality. Similarly, Kiswani (2015) posits that M\&A has a positive relationship with customer reactions. The study accentuates that the success of M\&A is dependent upon the positive reactions from its customers. Another study by Ebimobowei and Ekankumo (2012) also investigated the impact of M\&A on customer service using regression to analyse data collected. Their study provides evidence of an improved customer satisfaction in the post-M\&A period. This is following the wide acceptance of the combination exercise by customers.

Conversely, the studies of Christain and Mathias (2005) and Shukla and Gekara (2011) asserted that M\&A have a negative impact on customer satisfaction. Homburg and Burcerius (2005) evaluated the effect of M\&A on customer satisfaction. The result from their study showed an unfavourable impact. The findings of Shukla and Gekara (2011) also confirms this. The authors believe that M\&A has resulted in management shifting profitability strategies to increased market power, thereby raising customer prices. Oberg and Anderson (2002) previously pointed out that during M\&A management focuses on the transactions alone while disregarding the effects on its customers. Based on the above backdrop, we develop our second hypothesis that, $\mathrm{H} 2$; there is no significant difference between pre and post-M\&A customer satisfaction.

\subsubsection{Mergers \& Acquisitions and Learning and Growth Performance}

This performance dimension focuses on the value creation strategies of a firm through its investment in employees, in terms of research and development, increased employee satisfaction and employee productivity (Kaplan \& Norton, 1992). A fundamental expectation from M\&A is that the combined firm will be more efficient and its employees more productive. Kareem, Akinola and Oke (2014) conducted a study on the effects of M\&A on employee research and development $(R \& D)$. Descriptive statistics was used to analyse data. The result showed a positive significant 
impact of M\&A on employee R\&D in the area training and re-training of workers. Similarly, Ernest (2012) documents that the post M\&A period witnessed an increase in employee packages, which in turn reflected in a significant increase in employee productivity. A related study by Kuvuti (2013) examined the effects of mergers and acquisitions on employee efficiency. Using descriptive statistics, the findings revealed a positive relationship between mergers and acquisitions and employee productivity.

Conversely, Szucs (2014) employed the difference- in-difference estimation method to single out the causal effect of M\&A on Research and Development (R\&D) growth, intensity, and spending. The result from the study showed a substantial decrease in R\&D following M\&A. The study concluded that management becomes more risk averse after $M \& A$, and as a result R\&D practices are reduced. On employee productivity, Schuler and Jackson (2011) earlier emphasised that M\&A activities while having a positive impact on the shareholders the reverse may be the case for its employees. For example, management vision may be shifted from investing in their employees through research and development to profitability. In a recent study, Abdulrahaman (2016) argued that M\&A is not favourable. The study documents that M\&A resulted in stress, anxiety and fear of the loss of job, hence a negative impact on employees' productivity. Given the above arguments, we develop our third hypothesis that H3: There is no significant difference between the pre and post-M\&A learning and growth performance.

\subsubsection{Mergers \& Acquisitions and Internal Business Process Performance}

The internal business process performance is based on the efficiency and effectiveness of organisations operations. It presents the organisation with the means of accomplishing its objective through its enhancement in technological efficiency and innovations (Butler, Henderson \& Rainborn, 2011 and Kaplan \& Norton, 1992). Prior studies such as Cloodt, Hageborn and Kereneburg (2006) and Gantumor and Stephan (2007) documents that the increased size of companies through M\&A has a positive relationship with their technological performance which in turn improves the bottom line. Gantumor and Stephan (2007) examined the impact of M\&A practices on the technological and innovation performance of firms. The study employed regression analysis to analyse its data. Their result provides evidence that M\&A significantly impact organisations technical and innovation performance positively. This result is consistent with the operational synergistic effect of M\&A. Another study by Cloodt, Hageborn and Kereneburg (2006) opined that the impact of M\&A on technical and innovative performance would be dependent upon the nature of the merger. They examined the impact of M\&A on the technical and innovative performance of the firm. The study found that related organisations showed a positive impact while the unrelated firms presented a negative impact. In the same vein, Ismail and Rahim (2009) and Sufian and Habibilah (2009) employed the data envelopment analysis to investigate the effect of M\&A on banks technical efficiency. Their result showed that banks improved in terms of technical efficiency in the post-merger periods. A recent study of Entezarkheir and Moshiri (2015) studied the impact of M\&A on innovations using regression analysis. Their findings indicate that $M \& A$ has a positive impact on firms' innovations. This is because M\&A brings about an increase in resources, which in turn reflects in organisations innovation.

Nevertheless, the study of Ahuja and Katila (2001) had a different opinion. They document that the changes during acquisition may lead to the disruption of routine processes of the organisations, resulting in poor internal business process performance. Rezitis (2008) also had a similar view. The study examined the impact of M\&A on the technical efficiency of Malaysia banks using descriptive statistics for data analysis. The result from his study showed a decline in the firms' post- mergers and acquisitions technical efficiency. They, however, suggested that it could be a short - term effect of mergers. Consequently, we hypothesise that; H4: There is no significant difference between the pre and post-M\&A internal business process performance.

\subsubsection{Mergers \& Acquisitions and Environmental Performance}

The environmental performance describes the impact of the organisation's operations on the environment and society (Elkington, 1997). The measures consist of health and safety metrics, environmental programmes and products and services (Ahmed, Saleh \& Ibrahim, 2015 and Fauzi, Svensso \& Rahman, 2010). Environmental performance has attracted mixed acceptance over the years. A major synergistic expectation of the M\&A is that growth in firms' resources would enable them to focus on stakeholder practices. Aktas, Bodt and Cousin (2010) studied the effect of M\&A on environmental performance. Descriptive statistics and regression analysis were employed to analyse data. They found that environmental performance increased following the combination of social and environmentally friendly firms. They conclude that both entities tend to adopt the organisation's existing social and environmental practices. Hence they perform better. Similarly, Goyal and Dheer (2013) opined that M\&A creates a more efficient market and improve managerial performance thus reflecting in environmentally friendly activities. 
In contrast, Walley and Whitehead (1994) argued that environmental performance might be achieved only to the detriment of the firm's financial performance, therefore viewing it as value-destroying decisions for shareholders. They maintained that an increased environmental practice would attract greater costs, which may significantly impact firm's efficiency. Another study by Waddock and Graves (2006) found a negative relationship between M\&A and environmental performance. The study employed correlation analysis, $t$ - test of differences and Wilcoxon test for data analysis. They maintained that M\&A disrupts organisations' plans and attract huge conversion and transaction cost in the form of increased debt from takeovers, so as cost reduction measures they may not engage in environmental practices. Hence the findings are justified. In the light of the above, we hypothesise that, H5; There is no significant difference between the pre and post-M\&A environmental performance.

\subsection{Theoretical Framework}

The synergy theory of mergers forms the central framework for this study. The synergy theory of mergers and acquisitions was first mentioned by Ansoff in 1965. The theory is classified under the neoclassical theories. The central proposition of this theory is that organisations' embark on M\&A in expectation of positive returns for both the acquirer and the target. In essence, the theory implies that the main motive of the M\&A is synergy, where the two combined firms are expected to be greater than their individual entities, owing to reasons such as improvement in efficiency, financial and market power for the merged or acquired firms (Williamson, 1998). Consequently, from the synergy theory of mergers, managers have to evaluate performance not just on financial but encompassing non-financial dimensions of the organisations (Devos, Kadapakun \& Krishnamurthy, 2008 and Gaughan, 2007).Accordingly, a multidimensional performance measurement system such as the balanced scorecard is justified. From the studies of Anderibom and Obute (2015); Kareem et. Al (2015); Rezitis (2008) and Waddock and Graves (2006) and more specifically Kaplan and Norton's Balanced Scorecard the research framework for the study is developed.

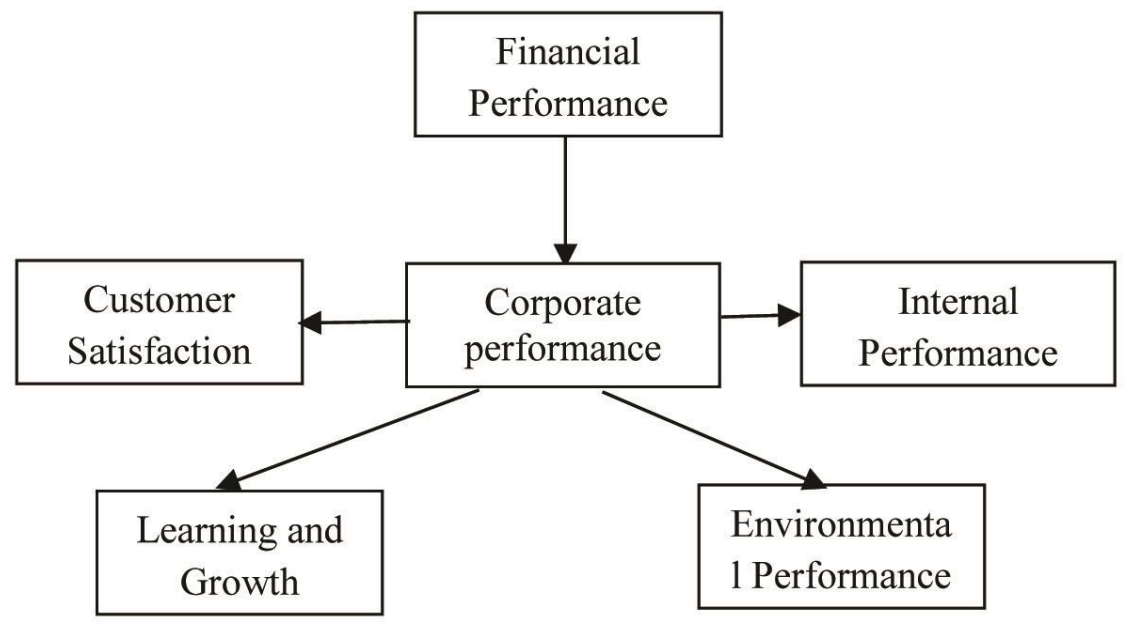

Figure 1. A Modified Balanced Scorecard

Source: Adapted from Kaplan and Norton (1992)

\section{Research Design}

The research population for this study is the Nigerian banking sector. This sector witnessed mergers and acquisitions in the year 2005. This was predicated on the directive of regulatory authority for a sound banking system, which required banks to increase their capital base from 2 billion to 25 billion. Consequently, the number of banks dropped significantly from 89 to 29 banks as at 31st December 2005. A census of the commercial banks that were involved in mergers and adopted the BSC formed the sample for the study. Consequently, five banks fell within these categories. They are Wema Bank Plc, United Bank for Africa Plc, First Bank Plc, Diamond Bank Plc, and Access Bank Plc. The data set for the study was gathered from the annual reports of the selected banks for five years pre (2000-2004) and five years post (2006-2010). The estimation technique for the data is the descriptive statistics and $\mathrm{t}$ - test of differences. This is because the issue of concern is a pre- and post- effect. Also followed in Table 1 and 2 is the constituent's banks and the description of the variables used in the study. 
Table 1. Constituents of Banks used for the study

\begin{tabular}{lll}
\hline S/N & Name of Banks & Consolidating Banks \\
\hline 1 & Diamond Bank & Diamond Bank, Lion Bank, African International Bank (AIB) \\
2 & First Bank of Nigeria Plc & First Bank of Nigeria Plc, FBN Merchant Bank, MBC International Bank \\
3 & Wema Bank Plc & Wema Bank, Lead Bank, National Bank of Nigeria \\
4 & United Bank for Africa & United Bank for Africa, Standard Trust Bank, Continental Bank \\
& Plc & \\
5 & Access Bank Plc & Marina Bank, Capital Bank, Access Bank \\
\hline
\end{tabular}

Table 2. Measurement of Corporate Performance Variables

\begin{tabular}{|c|c|c|c|}
\hline Variable & Metrics & Used by & $\begin{array}{l}\text { Apriori } \\
\text { expectation }\end{array}$ \\
\hline Financial & $\begin{array}{l}\text { Return on equity(ROE) } \\
\text { Return on Asset(ROA) }\end{array}$ & $\begin{array}{l}\text { Dincer, Hacioglu and Yuksel (2016); } \\
\text { Najjar and Kalaf (2012); Panicker and } \\
\text { Seshadri (2013) and Rostami, Goudarzi } \\
\text { and Zaj (2015) }\end{array}$ & + \\
\hline $\begin{array}{l}\text { Customer } \\
\text { satisfaction }\end{array}$ & $\begin{array}{l}\text { Growth in Current account (Gcurracc) } \\
\text { Growth in saving account(Gsavacc) } \\
\text { Growth in fixed deposit (Gfdep) }\end{array}$ & $\begin{array}{l}\text { Najjar and Kalaf (2012); Panicker and } \\
\text { Seshadri (2013) and Rostami, et. al., } \\
(2015)\end{array}$ & + \\
\hline Internal business & $\begin{array}{l}\text { Growth in property, plant and } \\
\text { equipment } \\
\text { Gppe) } \\
\text { Growth in online business (Gonlineb) } \\
\text { Growth in software andproduct } \\
\text { (Softw/p) } \\
\text { Credit Quality (Non-performing loan / } \\
\text { Total loan) }\end{array}$ & $\begin{array}{l}\text { Panicker and Seshadri (2013); Najjar and } \\
\text { Kalaf (2012) and Rostami, et. al., (2015). }\end{array}$ & + \\
\hline $\begin{array}{l}\text { Learning } \\
\text { growth }\end{array}$ & $\begin{array}{l}\text { Staff productivity (No of Employee/ } \\
\text { Profit) } \\
\text { (staff prod) } \\
\text { Growth in branches (grbranches) } \\
\text { Staff cost }\end{array}$ & $\begin{array}{l}\text { Dincer, Hacioglu and Yuksel (2016); } \\
\text { Najjar and Kalaf (2012) and Panicker and } \\
\text { Seshadri, (2013). }\end{array}$ & + \\
\hline Environment & $\begin{array}{l}\text { Environmental Programmes Cost } \\
\text { (emprcost) }\end{array}$ & $\begin{array}{l}\text { Ahmed, Saleh and Ibrahim, (2015) and } \\
\text { Fauzi, Svensso and Rahman (2010) }\end{array}$ & + \\
\hline
\end{tabular}

Researcher's Compilation (2016) 
3.1 Estimation of Results and Discussions

Table 3. Descriptive Statistics

\begin{tabular}{|c|c|c|c|c|c|c|}
\hline \multicolumn{4}{|c|}{ Pre-merger statistics } & \multicolumn{3}{|c|}{ Post-merger statistics } \\
\hline BSC Dimensions & Mean & Std. Deviation & $\begin{array}{l}\text { Std. } \\
\text { Mean }\end{array}$ & Mean & Std. Deviation & $\begin{array}{l}\text { Std. } \\
\text { Mean }\end{array}$ \\
\hline \multicolumn{7}{|c|}{ Financial dimension } \\
\hline ROA & 1.16 & 1.421 & .269 & .48 & .991 & .222 \\
\hline ROE & 12.71 & 15.172 & 2.867 & 3.35 & 7.576 & 1.694 \\
\hline \multicolumn{7}{|c|}{ Learning and growth Dimension } \\
\hline Grbranches & 479.78 & 702.660 & 135.227 & 2623.65 & 3404.225 & 761.208 \\
\hline Staff cost & 859887.65 & 1024645.578 & 184031.779 & 4219853.68 & 4590174.612 & 918034.922 \\
\hline Staff prod & 208.57 & 616.360 & 141.403 & 1010.57 & 1564.344 & 403.912 \\
\hline \multicolumn{7}{|c|}{ Internal business process dimension } \\
\hline Gppe & 1417281.11 & 1521859.384 & 257241.187 & 25584471.84 & 79349296.646 & 15869859.329 \\
\hline Gonlineb & 75.89 & 58.407 & 19.469 & 2737697.86 & 7242220.862 & 2737302.192 \\
\hline Softw/p & 859887.65 & 1024645.578 & 184031.779 & 4219853.68 & 4590174.612 & 918034.922 \\
\hline \multicolumn{7}{|c|}{ Customer satisfaction dimension } \\
\hline Gcurracc & 9185749.28 & 11147385.612 & 2229477.122 & 62555623.40 & 69883552.085 & 13976710.417 \\
\hline Gsavacc & 3453702.96 & 5633800.720 & 1104879.223 & 8490319.76 & 10725424.335 & 2145084.867 \\
\hline Gfdep & 8490319.76 & 10725424.335 & 2145084.867 & 65774083.48 & 78733719.144 & 15746743.829 \\
\hline \multicolumn{7}{|c|}{ Environmental dimension } \\
\hline $\begin{array}{l}\text { Env.programmes } \\
\text { cost. }\end{array}$ & 11284107.13 & 21022696.145 & 4291239.881 & & 28907198.693 & 5781439.739 \\
\hline
\end{tabular}

Source: Research's Compilation (2016)

The modified balanced scorecard approach was employed in the analysis of the descriptive statistics on pre- and post-merger performance of banks in Table 1. The approach incorporates five key perspectives of corporate performance; financial dimension, learning and growth dimension, internal business process dimension, customer satisfaction dimension and environmental dimension. First, for the financial dimension, the study examines ROA and ROE. As shown, the mean ROA and ROE for the pre-merger are 1.16 and 12.17 respectively while for the post-merger periods we have 0.991 and 7.576 respectively. The statistics suggest that on the average ROA appeared to be higher in the pre-merger period while ROE is higher in the post-merger period. Secondly, the learning and growth dimension was evaluated by the growth in branches (grbranches), staff cost and staff productivity. The mean statistic for the variables reveals that for grbranches (pre-merger $=479.78$, post-merger $=2623.65$ ), staff cost (pre-merger $=859887.65 \mathrm{mn}$, post-merger $=4219853 \mathrm{mn}$ ), for staff productivity (pre-merger $=208.575 \mathrm{mn}$, post-merger $=1010.57 \mathrm{mn}$ ). The results reveal that the growth in branches is higher in the post-merger periods than in the pre-merger periods, staff cost appeared to be lower in the pre-merger period, and staff productivity is higher in the post-merger period.

Thirdly, the internal business process dimension examined growth in property, plants and equipment, growth in online banking and software. The mean statistic for the variables reveals that for growth in property, plants and equipment (pre-merger $=1417281.11$, post-merger $=25584471.84$ ), for on growth in online banking (pre-merger $=75.89$, post-merger $=2737697.86)$, for software $/$ product $($ pre-merger $=859887 \mathrm{mn}$, post-merger $=4219853 \mathrm{mn})$. The results reveal that the average growth in property, plants and equipment is lower in the pre-merger period, on line banking growth is higher in the post-merger period while software/products are also higher in the post-merger period. Fourthly, for the customer satisfaction dimension, the study examined growth in current account (gcurracc), (pre-merger $=9185749.28$, post-merger $=62555623.40$ ), growth in savings account (gsavacc) (pre-merger $=3453702.96$, post-merger $=8490319.79$ ), and growth in fixed deposit accounts (gfdep) (pre-merger $=8490319.76$, post-merger $=65774083.48$ ). The results revealed that the average growth in current account (gcurracc) is higher in 
the post-merger periods than in the pre-merger periods, average growth in growth in savings account is lower in the pre-merger period and growth in fixed deposit account is higher in the post-merger period. Finally, the environmental dimension examined the environmental programmes cost. The mean statistic for the variable reveals that for the pre-merger period, the average environmental cost is 11284107.13 while for the post-merger period; the average value is about 28907198.693. The values show that environmental cost is higher in the post-merger period than in the pre-merger period.

Table 4. T-test of differences between pre- and post-merger periods

\begin{tabular}{lllll}
\hline BSC Dimensions & Mean diff & t-value & $\begin{array}{l}\text { Sig. } \\
(2 \text {-tailed })\end{array}$ & Std. error diff
\end{tabular}

Financial dimension

ROE

9.362

2.538

$0.015^{*}$

3.690

ROA

1.818

.076

0.0369

Financial dimension PCA index

0.414

2.641

$0.010^{*}$

0.020

Learning and growth Dimension (LGD)

Grbranches

$-214.872$

$-3.193$

$.003 *$

671.344

Staff cost

$-3359966.0$

$-3.963$

$.000 *$

847816.936

Stafffprod

$-801.993$

$-2.049$

$.049 *$

391.431

LGD PCA index

3940.1

4.091

$0.00 *$

101.382

Internal business process dimension (IBPD)

Gppe

-24167190 .

$-1.808 \quad .076$

13369631.361

Gonlineb

$-2737621.9$

$-1.146$

.271

2389313.237

Softw/p

$-18.115$

$-1.842$

.083

9.834

IBPD PCA index

16432.011

$-2.655$

.1000

10.482

Customer satisfaction dimension

Gcurracc

$.000 *$

14153409.565

Gsavacc

$-12504784$

$-2.412$

$.020 *$

5184354.446

Gfdep

$-57283763.720$

$-3.605$

$.001 *$

15892178.274

Customer dimension PCA Index

$-39402310.1$

$-3.812$

$.000^{*}$

168490.032

Environmental dimension

Env.programmes Cost.

$-1589367.635$

$-.221$

.826

7246369.147

Source: Researchers' compilation (2016). * Sig at 5\%

In Table 3, the result for the t-test for statistical significance in the differences is examined. In the financial dimension, we observe the existence of significance difference in ROE as the t-value (2.538) is significant ( $\mathrm{p}=0.015)$ at $5 \%$ level, but this is not the case for ROA where the t-value of 1.181 is not significant at $5 \%$ level. For robustness, we test for statistical difference using a performance dimension index generated from principal component analysis (PCA) of ROA and ROE. The result appears significant at 5\% and hence we conclude that there is a significant difference between BSC-financial performance dimension in pre- and post-merger periods for the sampled banks. 
These findings is in line with the studies of Anderibom and Obute (2015) and Rani, Yadav and Jain (2015) that asserts that M\&A improved the financial performance of organisations.

The learning and growth dimension shows the existence of significance difference for growth in branches, staff cost and staff productivity as their t-values; (3.193), (3.963) and (2.049) are all significant at 5\% level. For robustness, we test for statistical difference using the PCA learning and growth dimension index. The result appears significant at 5\% and hence we conclude that there is a significant difference between BSC-learning and growth dimension in pre- and post-merger periods for the sampled banks. This finding is consistent with the studies of Kareem, Akinola and Oke (2014) and Kivuti (2013). This implies that the improvement in the financial bottom line enabled the banks to focus on employee friendly programmes, like staff training, hence the improvement in staff productivity.

In the internal business process dimension, there is no significant difference in the growth in property, plant and equipment, growth in online banking and software, as their t-values; (1.808), (1.146) and (1.842) are not significant at 5\% level. For robustness, we test for statistical difference using the PCA internal business dimension index. The result is not significant at 5\% and hence we conclude that there is no significant difference between BSC- internal business process dimension in pre- and post-merger periods for the sampled banks. This implies that M\&A did not give rise to an improvement in technological innovations and efficiency, owing to disruption in organisations processes in the course of mergers and acquisitions. This assertion is in line with the conclusion of Ahuja and Katila, (2001) and Rezitis (2008).

In the customer satisfaction dimension, we observe the existence of significance difference for growth in current account (gcurracc), growth in savings account (gsavacc) and growth in fixed deposit accounts are all significant at 5\% as their t-values; (3.771), (2.412) and (3.605) are all significant at 5\% level. For robustness, we test for statistical difference using the PCA customer dimension index. The result appears significant at $5 \%$ and hence, we conclude that there is a significant difference between BSC-customer dimension in pre- and post-merger periods for the sampled banks. The findings of Johnson, Earnest and Samuel (2015); Kiswani (2015) and Onaolapo and Ajala (2012) corroborate this result.

Finally, in the environmental dimension, we observe that the existence of significance difference for environmental (env cost) is not significant at $5 \%$ as the t-values; $(0.221)$ and hence we conclude that there is no significant difference between BSC-environmental dimension in the pre- and post-merger periods for the sampled banks. This finding is consistent with the assertion of Waddock and Graves (2006) and Walley and Whitehead (1994) that M\&A have a negative impact on environmental performance.

\subsection{Discussion of Findings}

The results of the study suggest that M\&A improved the performance of Nigerian banks evaluated in terms of financial, learning and growth and customer satisfaction performances. However, in the area of environmental performance there was no significant difference in the provisions for environmental cost between the pre- and post-merger periods. This suggests that banks may not have taken environmental performance seriously, and this calls for concern. These findings are in line with the assertion of Waddock and Graves (2006) that mergers and acquisitions activity absorbs management attention and creates significant cost. Hence corporate environmental practices may be eliminated as cost reduction measures, resulting to the abysmal performance of that dimension. In the same vein, the internal business process performance reflected mixed results. The credit growth was significant, while the growth in property, plant and equipment, online banking and software's were not significant. This implies that on the average, banks did not give attention to the technological facet of their combination. This may be the resultant effect of showing more concerns on profitability. This conclusion is in congruence with the findings of Ahuja and Katila (2001) and Haspeslag and Jemison (1991) that M\&A tend to divert managerial attentions from important activities such as innovations and also, the process of acquisition may disrupt the internal business processes of organisations.

\section{Conclusion and Policy Implications}

The broad objective of this study is to examine the impact of mergers and acquisitions on the corporate performance using a modified Balanced Scorecard (BSC). Prior studies on post- mergers and acquisitions performance have measured performance using the traditional financial performance measure. This study presents a more robust evidence and clarity of the impact of M\&A on corporate performance by modifying the BSC to include a fifth dimension, which is the environment. The study concludes from the significant differences in the pre and post means of the performance dimension that M\&A has a positive impact on the financial, customer and learning and growth perspective. 
By these findings, this study advocates considerable policy recommendations. First, given the poor performance of the environmental dimension, organisation's should implement corporate environmental strategies, such as, setting up environmental management and audit systems, integrating environmental issues into management decisions so as to ensure top management commitment and support to environmental practices. Also, environmental impact should be incorporated into organisations' performance evaluation systems. Secondly, the organisation's operational effectiveness and efficiency are dependent upon the improvement of its internal business processes. Therefore it is recommended that strategies such as research and development initiatives are planned for achieving the best possible utilisation of organisations technological and innovative capacities. Thirdly, management should strengthen their customer's satisfaction and learning and growth measures by introducing customers and employees' friendly practices such as relationship management systems, training and development programmes, support services and interaction systems. This in no small measure may reflect positively in the organisation's bottom line (financial performance). Finally, management should develop effective strategies towards monitoring performance in the proposed performance dimensions, in other to improve the long-term profitability of the organisation.

\section{Summary of Contribution}

This study gives an additional insight to the performance paradox of mergers and acquisitions. Specifically, it advances an empirical operationalisation of the sustainability balanced scorecard by introducing and practicalising the environmental dimension of balanced scorecard. It thus contributes to the emerging literatures on BSC and M\&A performance.

\section{References}

Abdulrahaman, S. (2016). The relevant factors of employee efficiency as a multidimensional constructs in Nigerian banking sector after consolidation. International Journal for Research in Business, Management and Accounting, 2(4), 216 -233.

Afolabi, J.A. (2011). Mergers and acquisitions: Effect on financial performance of manufacturing companies in Pakistan. Middle-East Journal of Scientific Research, 21(4) 689 - 699.

Ahmed, M., \& Ahmed, Z. (2014). Mergers and acquisitions: Effect on financial performance of manufacturing companies of Pakistan. Middle-East Journal of Scientific Research, 21(4), 689-699.

Ahmed, A. D., Saleh, M.B., \& Ibrahim, M. (2015). Assessment of the non- financial measures of performance in deposit money banks in Nigeria. Journal of Accounting and Taxation, 7(8), 131- 136. http://dx.doi.org/10.5897/JAT2015.0188

Ahuja, G., \& Katila, R. (2001). Technological acquisitions and the innovation performance of acquiring firms: A longitudinal study. Strategic Management Journal, 22(3), 197 - 220. http://dx.doi.org/10.1002/smj.157

Akben-Selcuk, E., \& Altiok-Yilmaz, A. (2011).The impact of mergers and acquisitions on acquirer performance: Evidence from Turkey. Business and Economics Journal, 2(22), 1 - 8.

Akinbuli, S. F., \& Kelilume, I. (2013). The effects of mergers and acquisitions on corporate growth and profitability: Evidence from Nigeria. Global Journal of Business Research, 7(1), 43-58.

Aktas, N., Bodt, E., \& Cousin, J. (2010). Do financial markets care about socially responsibility investment: Evidence from mergers and acquisitions. Economic Journal, 116(34), 1-33.

Anderibom A. S. \& Obute C. O. (2015). The effects of mergers and acquisitions on the performance of commercial banks in Nigeria. International Journal of Education and Research, 3(4), 93 -112.

Ansari, A., \& Riasi, A. (2016). Customer Clustering Using a Combination of Fuzzy C-Means and Genetic Algorithms. International Journal of Business and Management, 11(7), 59-66. http://dx.doi.org/10.5539/ijbm.v11n7p59

Ansoff, H. I. (1965). The firm of the future. Harvard Business Review, 43(5), 62-178.

Anyanwu, S. A. C., \& Agwor, T. C. (2015). Impact of mergers and acquisitions on the performance of manufacturing firms in Nigeria. An International Multidisciplinary Journal, 9(2), 156-165. http://dx.doi.org/10.4314/afrrev.v9i2.12

Ashfaq, K. (2014). Investigating the impact of mergers and acquisitions on post-merger financial performance (relative and absolute) of companies: Evidence from non-financial sector of Pakistan. Research Journal of Finance and Accounting, 5(13), 88-101. http://dx.doi.org/10.6007/ijarbss/v4-i11/1307 
Ashfaq, K., Usman, M., Hanif, Z., \& Yousaf, T. (2014). Investigating the impact of merger and acquisition on post-merger financial performance of companies: Evidence from non-financial sector of Pakistan. International Journal of Academic Research in Business and Social Sciences, 4(11) 258 -281. http://dx.doi.org/10.6007/IJARBSS/v4-i11/1307

Butler, J.B., Henderson, S.C., \& Raiborn, C. (2011). Sustainability and the balanced scorecard: Integrating green measures into business reporting. Management Accounting Quarterly, 12(2), 1-10

Christian, H., \& Mathias, B. (2005). A marketing perspective on mergers and acquisitions: How marketing integration affects post-merger performance. Journal of Marketing, 69(1), 95-113. http://dx.doi.org/10.1509/jmkg.69.1.95.55510

Cloodt, M., Hageborn, J., \& Kranenburg, H.V. (2006). Mergers and acquisitions: Their effects on the innovative performance of companies in high industries. Research policy, 35(1), 642 - 654. http://dx.doi.org/10.1016/j.respol.2006.02.007

Devos, E., Kadapakkam, P., \& Krishnamurthy, S. (2008). How do mergers create value? A comparison of taxes, market power, and efficiency improvements as explanations for synergies. The Review of Financial Studies, 22(3), 1179-1211. http://dx.doi.org/10.1093/rfs/hhn019

Dincer, H., Hacioglu, U., \& Yuksel, S. (2016). Balanced scorecard based performance assessment of Turkish banking sector with analytic network process. Journal of Decision Sciences Applications, 1(1), 01-21.

Earnest, I.E., (2012). Bank consolidation in Nigeria: Marketing implications and challenges for the surviving banks. Arts and Social Sciences Journal, 2012 (31), 1-15.

Ebimobowei, A., \& Ekankumo, B. (2012). Customers service strategy and commercial banks survival in a postconsolidation era in Nigeria. American International Journal of Contemporary Research, 2(8), 142 -153.

Elkington, J. (1997). The triple bottom line for 21st-century business. Environmental Quality Management, 11(2), $1-10$.

El - Zuhairy, H. E., Taher, A., \& Shafei, I. (2015). Post-mergers and acquisitions: The motives, success factors and key success indicators. Eurasian Journal of Business and Management, 3(2), 1-11. http://dx.doi.org/10.15604/ejbm.2015.03.02.001

Entezarkheir, M., \& Moshiri, S. (2015). Merger induced changes of innovation: Evidence from a panel of US firms. Unpublished paper, Huron University College, Western University.

Eskandari, M., Roudabr, N., \& Kamfiroozi, M. (2013). Banks' performance evaluation model based on the balanced scorecard approach, fuzzy dematel and analytical network process. International Journal of Information, Security and System Management, 2(2), 191-200.

Etim, R.S., \& Agara, I.G. (2011). The balanced scorecard: The new performance management paradigm for Nigerian firms. International Journal of Economic Development Research and Investment, 2(3), 64 - 73.

Fauzi, H., Svensson, G., \& Rahman, A. (2010). Triple bottom line as sustainable corporate performance: A proposition for the future. Sustainability, 2(5), 1345-1360. http://dx.doi.org/10.3390/su2051345

Gantumor, T., \& Stephan, A. (2007). Mergers and acquisitions and innovation performance in the telecommunications equipment industry. Discussion paper, Humboldt University, Berlin.

Goyal, K.C., \& Dheer, P. (2013). Implications of mergers and acquisitions on stakeholders: A case study of reliance industries limited. Pacific Business Review International, 6(2), 1-8.

Grigorieva, S., \& Petrunina, T. (2015). The performance of mergers and acquisitions in emerging capital markets: New angle. Journal of Management Control, 26(4), 377 - 403. http://dx.doi.org/10.1007/s00187-015-0219-9

Guaghan, P.A. (2007). Mergers, acquisitions and corporate restructuring (4th ed.). New York: Wiley and Sons.

Haspeslagh, P., \& Jemison, D. (1991). Managing acquisitions: Creating value through corporate renewal. New York: The Free Press.

Homburg, C., \& Bucerius, M. (2005). A marketing perspective on mergers and acquisitions: How marketing integration affects post-merger performance. Journal of Marketing, 69(1), 95-113. http://dx.doi.org/10.1509/jmkg.69.1.95.55510 
Horngren, C. T., Foster, G., \& Datar, S. M. (2005). Cost Accounting: A managerial emphasis. (6th ed.). Englewood Cliffs: Prentice Hall.

International Financial Reporting Standard. (2008). Consolidated without any application, part A: The conceptual framework and requirement. London: IFRS foundation.

Ismail, T. H., Abdou, A. A., \& Annis, R. M. (2011). Review of literature linking corporate performance to mergers and acquisitions. The Review of Financial and Accounting Studies, 1, 89-104.

Ismail, \& Rahim, (2009). Impact of mergers and acquisitions on efficiency and productivity in Malaysia commercial banks. International Journal of Economics and Finance, 1(2), 225. http://dx.doi.org/10.5539/ijef.v1n2p225

Johnson, Y., Ernest, K., \& Samuel, A. (2015). The Impact of mergers and acquisitions on service quality of banks in Ghana: Case study of Eco Bank and Access Bank Ghana. International Journal of Business and Management, 10(12), 167 -180. http://dx.doi.org/10.5539/ijbm.v10n12p167

Kaplan, R.S., \& Norton, D.P. (1992). The balanced scorecard: Measures that drive performance. Harvard Business Review, 70(1), 71-79.

Kareem, A. O., Akinola, G.O., \& Oke, E. A. (2014). Effect of mergers and acquisitions on employee development: The Nigerian banking industry experience. Fountain Journal of Management and Social Sciences, 3(2), 47-56.

Kiswani, Z. (2015). Do the customers matter in mergers and acquisitions? A case survey study about financial performance and customer reaction on mergers and acquisitions (Master's thesis), Lund University, Sweden.

Kivuti, M. (2013). The influence of mergers and acquisitions on employee performance. (Master's thesis) University of Nairobi, Kenya.

Najjar, S., \& Kalaf, K. (2012). Designing a balanced scorecard to measure a bank's performance: A case study. International Journal of Business Administration, 3(4), 44 - 53.

Oberg, C. (2014). Customer relationship challenges following international acquisitions. International Marketing Review, 31(3), 259-282. http://dx.doi.org/10.1108/IMR-10-2012-0166

Oberg, C., \& Anderson, H. (2002). Do customers matter in mergers and acquisitions literature? Paper presented at 12th Nordic workshop on inter-organisational research, Kolding, Denmark.

Oh, J.H., Peter, L.D., \& Johnston, W.J. (2014). Who's acquiring whom: Experimental evidence of firm size effect on mergers and marketing sales tasks. Industrial Marketing Management, 43(6), 1044. http://dx.doi.org/10.1016/j.indmarman.2014.05.016

Olagunju, A., \& Obademi, O. (2012). An analysis of the impact of mergers and acquisitions on commercial banks performance in Nigeria. Research Journal of Finance and Accounting, 3(7), 91-101.

Omoye, A. S., \& Aniefor, S. J. (2016). Mergers and acquisitions: The trend in business environment in Nigeria. Accounting and Finance Research, 5(2), 10 -19.

Panicker, S., \& Seshadri, V. (2013). Devising a balanced scorecard to determine standard chartered banks performance: A case study. International Journal of Business and Development, 2(2), 35 - 42.

Rani, N., Yadav, S., Jain, P.K. (2015). Financial performance analysis of mergers and acquisitions: Evidence from India. International Journal of Commerce and Management, 25(I4), $402-423$. http://dx.doi.org/10.1108/IJCoMA-11-2012-0075

Rezitis, A.N. (2008). Efficiency and productivity effects of banks mergers: Evidence from the Greek banking industry. Economic Modelling, 25(2), 236-252. http://dx.doi.org/10.1016/j.econmod.2007.04.013

Rigby, D., \& Bilodeau, B. (2013). Management tools and trends 2013. London: Bain \& Company.

Rostami, M., Goudarzi, A., \& Zaj, M. (2015). Defining balanced scorecard aspects in banking industry using fahp approach. International Journal of Economics and Business Administration, 1(1), 25-38.

Sabri, F. M., Ezman, S.M., \& Zainal, H. (2015). The impact of banks' mergers and acquisitions towards stock performance of the rival banks in Thailand. Conference on business management research, School of business management, Malaysia.

Schuler, R., \& Jackson, S. (2011). Human resources issues and activities in mergers and acquisitions. European Management Journal, 19(3), 239-253. http://dx.doi.org/10.1016/S0263-2373(01)00021-4 
Sheidu, A. D., \& Yusuf, H. (2015). Bank consolidation and improvement of shareholder value: An empirical evaluation of return on capital employed following bank mergers in Nigeria. American International Journal of Contemporary Research, 5(5) 240 - 246.

Sherman, A. J. (2011). Mergers and acquisitions from A to Z, (3rd ed.). USA: Library of congress catalogue.

Shimizu, K., \& Hitt, M. A. (2005). What constraints or facilitates divestitures of formerly acquired firms: The effects of organisational inertia. Journal of Management, 31(1), 50 -72. http://dx.doi.org/10.1177/0149206304271381

Shukla. A., \& Gekara, M. (2011). Measurement of consumer satisfaction during post- merger period. International Journal of Business Management and Economic, 2(1), 140-151.

Sudarsanam, S., \& Mahate, A. A. (2006). Are friendly acquisitions too bad for shareholders and managers: Long-term value creation and top management turnover in hostile and friendly acquirers. British Journal of Management, 17(1), 7 - 30. http://dx.doi.org/10.1111/j.1467-8551.2006.00476.x

Sufian, F., \& Habibullah, M. S. (2009). Do mergers and acquisitions leads to a higher technical and scale efficiency? A counter evidence from Malaysia. African Journal of Business Management, 3(8), 340-349.

Sulaiman, L.A. (2012). Does restructuring improve performance: An industry analysis of Nigerian oil \& gas sector, Research Journal of Finance and Accounting, 3(6), 55.

Szucs, F. (2014). Mergers, acquisitions and research, development: Asymmetric effects on acquirers and targets. Research Policy, 43(1), 1264-1273. http://dx.doi.org/10.1016/j.respol.2014.03.007

Waddock, S. A., \& Graves, S. B. (2006). The impact of mergers and acquisitions on corporate stakeholders practices. Journal of Corporate Citizenship, 22, 91 - 109. http://dx.doi.org/10.9774/GLEAF.4700.2006.su.00011

Walley, N., \& Whitehead, B. (1994). It's not easy being green. Harvard Business Review, 72(3), 46 -52.

Wang, D., \& Moini, H. (2012). Performance assessment of mergers and acquisitions: Evidence from Denmark. E-Leader Berlin, 1-15. 